\title{
三元系錯体を用いたカルシウムイオン放出 電気化学デバイスの作製と評価
}

\author{
廣田 憲治 ${ }^{1}$, 加 藤 亮 ${ }^{2}$, 澤田 和明 ${ }^{1}$, 服部 敏明*1
}

\begin{abstract}
電極活性陽イオン界面活性剤と $\mathrm{Ca}^{2+}$ が高分子陰イオンと静電的に結合した三元系錯体を調製し，この三元 系錯体を含むカーボンペースト $(\mathrm{CP})$ 電極により $\mathrm{Ca}^{2+}$ 放出電気化学デバイスを作製した．ポリビニル硫酸 $\left(\mathrm{PVS}^{-}\right)$とその半当量の 11-フェロセニルトリメチルウンデシルアンモニウム $\left(\mathrm{FeTMUA}^{+}\right)$を含む混合溶液 を調製し，その混合溶液に塩化カルシウムを加えて三元系錯体の沈殿を得た．FeTMUA ${ }^{+} に$ 応答する脂溶性 陽イオン選択性電極と $\mathrm{Ca}^{2+}$ 選択性電極を用いて, FeTMUA・PVS 錯体と Ca・PVS 錯体の性質を調べた. FeTMUA・PVS 錯体に比べて Ca・PVS 錯体の生成能は大きくないことが分かった. FeTMUA・Ca・PVS の 三元系錯体を内包する $\mathrm{CP}$ 電極は, FeTMUA ${ }^{+}$が吸着した $\mathrm{CP}$ 電極とは異なる高電位に酸化波が観測された. 三元系錯体量を変えることで数種の $\mathrm{CP}$ 電極を調製し， 5 分間の定電位電解後の $\mathrm{Ca}^{2+}{ }^{2}$ 放出量を原子吸光分析 によって算出した，CP 電極での三元系錯体含有量が多い場合には無電解時でも $\mathrm{Ca}^{2+}$ の放出があったが，少 量であれば無電解時での $\mathrm{Ca}^{2+}$ の放出がなかった. $\mathrm{CP}$ を先端口径 $500 \mu \mathrm{m}$ のポリプロピレンチップに充填し, $\mathrm{Pt}$ 線を挿入することで $\mathrm{Ca}^{2+}$ 局所放出電気化学プローブを作製し, CCD 型半導体 $\mathrm{Ca}^{2+}$ イメージセンサーを使 用して $\mathrm{Ca}^{2+}$ の放出挙動を調查した．プローブ直下の近傍でのみ $\mathrm{Ca}^{2+}$ 濃度が時間とともに上昇し，それ以外 の領域では， $\mathrm{Ca}^{2+}$ 濃度がまったく上昇しなかった。 また，イメージセンサーの解析から， $\mathrm{Ca}^{2+}$ の放出が時間 をおいて 2 段階で行われることが明らかになった．以上のことから，本電気化学的手法により局所だけに $\mathrm{Ca}^{2+}$ が放出できることが示された. 同時に, 微量な $\mathrm{Ca}^{2+}{ }^{2}$ 放出プローブの研究に $\mathrm{CCD}$ 型半導体 $\mathrm{Ca}^{2+}$ イメージ センサーが有用であることを示した。
\end{abstract}

\section{1 緒言}

生きた細胞及び生体組織を刺激し，その挙動を観察する バイオイメージングは, 生体活動ならびに生命の進化の解 明において有用である，その際，細胞に摂動を与える刺激 法とその応答挙動を知る検出法が重要となる. 細胞の刺激 法は, 物理刺激 ${ }^{122)}$, 電気刺激 ${ }^{3)}$, 化学刺激等がある. 特に, 化学刺激は, 細胞表面にある受容体に対して選択的に作用 することができるので, 生体のメカニズムを知る上で有用 な方法となる. 化学刺激の方法には, マイクロピペットや フロー系を利用した刺激物質のインジェクション, イオン トフォレシス ${ }^{4)}$ ，ケージド化合物への光照射による刺激物 質の放出)などがある. マイクロピペット添加の利点は, 水に溶けた様々な刺激物質の投与が簡便に行える点であ る. しかし, 水溶液の添加では細胞の移動や体積変化が起

\footnotetext{
*E-mail : thattori@ee.tut.ac.jp

${ }^{1}$ 豊橋技術科学大学電気・電子情報工学系 : 441-8580 愛知県豊 橋市天白町雲雀ヶ丘 1-1

2 豊橋技術科学大学教育研究基盤センター：441-8580 愛知県豊 橋市天白町雲雀ヶ丘 1-1
}

こり, 圧力が刺激になる場合もあり, さらに, 水溶液が広 域に拡散して局所のみに刺激を行うことは困難である場合 がある. 著者らは Compound 48/80の添加による肥満細胞 中のヒスタミン挙動のイメージングの研究で, マイクロピ ペットで刺激物質を含む溶剂の添加は肥満細胞全体を刺激 し，また，添加によって細胞が移動してしまうことを観測 した ${ }^{6)}$.

ケージド化合物5゙では, 生理活性を一時的に失わせた物 質に光を照射することで, 脱保護して瞬間的に元の生理活 性物質が放出される。このケージド化合物を用いる利点 は, 光照射をピンポイントに行うことで, 局所的かつ選択 的に生理活性物質を放出することが可能な点にある。しか し，照射光が細胞に直接的な刺激を与える恐れがあり，あ らかじめ保護された生理活性物質を細胞に導入する処理を しなければならず，高価で簡便性にそしく，侵襲の少ない 観察は行えない.

$\mathrm{Ca}^{2+}$ は細胞内には非常に低濃度しか存在しないため, 細 胞内の情報伝達物質として知られている7) . 一方で, $\mathrm{Ca}^{2+}$ は細胞外に数 $\mathrm{mmol} \mathrm{L}^{-1}$ 程度存在し, 一般的には $\mathrm{Ca}^{2+}$ の細 胞外濃度変化は大きな刺激とはならない. しかし，筋肉の 


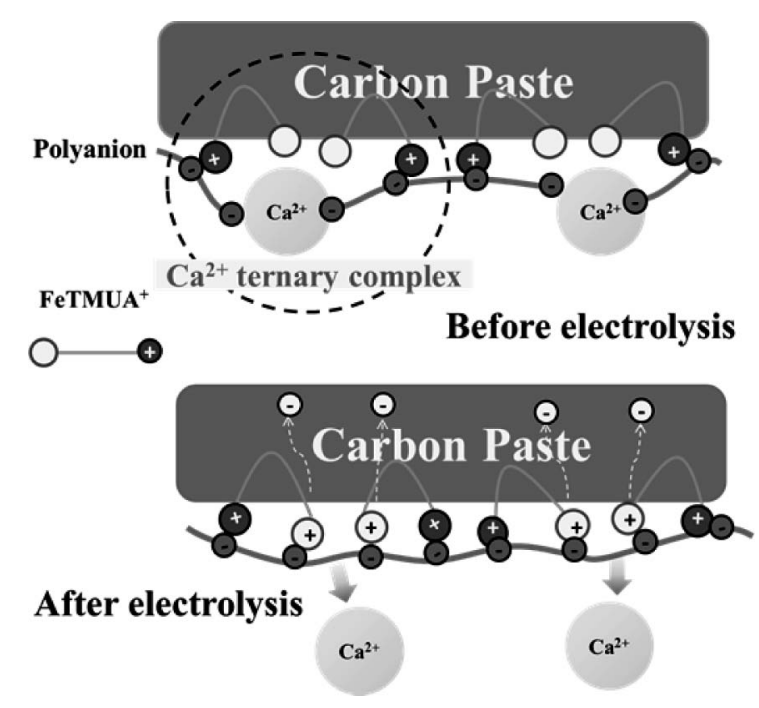

Fig. 1 Model of ternary complex before and after the electrolysis

収縮作用には $\mathrm{Ca}^{2+}$ で駆動するスイッチが存在し, 細胞外の $\mathrm{Ca}^{2+}$ 濃度がその収縮に重要な寄与をしている ${ }^{8)}$ 。また, 細 胞膜を処理したツリガネ虫の柄の収縮では, 筋収縮と異な りアデノシン三リン酸 (ATP) がなくても細胞外の $\mathrm{Ca}^{2+}$ 濃 度の増加で柄が収縮することが知られている ${ }^{9)}$.

$\mathrm{Ca}^{2+}$ 電気化学的に制御して溶液に放出する試みは, $\mathrm{Ca}^{2+}$ 選択性可塑化ポリ塩化ビニル（PVC）膜を用いて $\mathrm{Ca}^{2+}$ を移動させるクーロメトリー ${ }^{10)}$ がある. また, 電極で水素 イオンを発生させることで電極上の炭酸カルシウムからカ ルシウムイオンを遊離させて, アルギン酸 Ca のゾルゲル

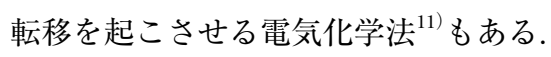

本研究では, 電極活性物質と高分子電解質との錯形成 ${ }^{12}$ 及び高分子電解質と多価イオンの錯形成に着目し, 電解に よる $\mathrm{Ca}^{2+}$ 局所放出電気化学デバイスを開発した. 今回の三 元系錯体による $\mathrm{Ca}^{2+}$ の放出原理を Fig. 1 に示す. 電解前に 三元系錯体は電荷の中性を保っている. そこで, 電解によ り FeTMUA ${ }^{+}$が酸化されると, 2 価の陽イオンになり, 同 時に三元系錯体の電荷を中和するために, $\mathrm{Ca}^{2+}$ が放出され る.この機構を基に, 微小なデバイスから電解により $\mathrm{Ca}^{2+}$ が実際に放出されているかを評価した. $\mathrm{CCD}$ 型 $\mathrm{Ca}^{2+}$ イ メージセンサーを用いることで, デバイスからの微量な $\mathrm{Ca}^{2+}$ の電解放出がリアルタイムに確認できた結果につい て報告する。

\section{2 実験}

\section{$2 \cdot 1$ 試 薬}

11-フェロセニルトリメチルウンデシルアンモニウムブ ロミド (FeTMUABr)，テトラキス(4-クロロフェニル)ホ ウ酸カリウム (KTCPB)，2-ニトロフェニルオクチルエー テル（NPOE）は, 同仁化学研究所製試薬を購入した，ポ
リビニル硫酸カリウム (KPVS), 塩化カルシウム, 塩化カ リウム, テトラヒドロフラン (THF), 酢酸リチウム, 硝酸 カルシウム・四水和物は, 和光純薬工業製試薬を購入し た。ジ- $n$-オクチルフタル酸（DOP）は，関東化学製試薬 を購入した. ヘパリン，ポリスチレンスルホン酸ナトリウ ム (NaPSS), ポリ塩化ビニル (PVC), 10,19-ビス[(オク タデシルカルバモイル)メトキシアセチル]-1,4,7,13,16-ペ ンタオキサ-10,19-ジアザシクロヘネイコサン（K23E1）, 1,3,5,7,9,11,13,15-オクタ(プロピルメタクリル)ペンタシ クロ $\left[9.5 \cdot 1 \cdot 1^{3,9} \cdot 1^{5,15} \cdot 1^{7,13}\right]$ オクタシロキサン (POSS) は, シ グマアルドリッチ製試薬を購入した. $1 \mathrm{~mol} \mathrm{~L}^{-1}$ トリス塩酸 塩緩衝液（分子生物学用特製試薬 $\mathrm{pH}$ 7.6）は, ナカライテ スク製試薬を購入した。試薬を水に溶かす際は, ミリポア Direct-Q UV3 超純水システム（逆浸透膜処理, UV 処理, イオン交換処理，フィルターろ過処理）を通した水を使用 した.

\section{$2 \cdot 2$ 界面活性剤電極と $\mathrm{Ca}^{2+}$ 選択性電極による電位差測定}

今回使用した界面活性剂電極年) 及び $\mathrm{Ca}^{2+}$ 選択性電極 ${ }^{14)}$ は参考文献を基に次の組成でそれぞれ秤量し，THFに溶解 させることで膜溶液を調製した，界面活性剤に応答する膜 には, $25 \%$ の PVCと $75 \%$ の NPOE を含み, $\mathrm{Ca}^{2+}$ 選択性膜 には, $32.5 \%$ の PVC, $65.0 \%$ の NPOE, $2.0 \%$ の K23E1, $0.5 \%$ のTCPB を含んでいる. シャーレ上で膜溶液の $\mathrm{THF}$ を揮発させたのち, 直径 $5 \mathrm{~mm}$ の膜をくり妨, ポリ 塩化ビニル製の管（直径 $5 \mathrm{~mm}$, 長さ $12 \mathrm{~cm}$ ）の一端に膜 を接着させた.いずれの電極も管内部の溶液には $\mathrm{KCl}$ 飽和 水溶液を使用し, 銀塩化銀電極を装着した。また, 参照電 極には東車電波製の DS-20S を使用し，その内部液には KCl 飽和水溶液, 外部溶液には $0.1 \mathrm{~mol} \mathrm{~L}^{-1}$ の酢酸リチウムを充 填した. 電位差計は, 東亜電波製の ION METER IM-40S を 用いた。

$2 \cdot 3$ カーボンペースト（CP）電極によるサイクリック ボルタンメトリー

カーボン粉末 $1 \mathrm{~g}$ にDOP $300 \mu \mathrm{L}$ を加えてめのう乳鉢に より混合して CPを調製した. 調製した CPに乾燥した適量 の三元系錯体をさらにメノー乳鉢で混合し，それを内径 $3 \mathrm{~mm}$ 電極 (BAS 製 CPEカーボンペースト電極)に詰めて, サイクリックボルタンメトリーを行った. 七ルに $10 \mathrm{mmol}$ $\mathrm{L}^{-1}$ の $\mathrm{NaCl}$ 水溶液 $10 \mathrm{~mL}$ を充填し, 参照電極には飽和 $\mathrm{KCl}$ の $\mathrm{Ag} / \mathrm{AgCl}$ 電極，対極には Pt wireを使用し，BAS 製 CV-50W 用いて 0 $1000 \mathrm{mV}$ まで電位を $100 \mathrm{mV} \mathrm{s}{ }^{-1}$ で掃 引し, サイクリックボルタモグラムを得た。 


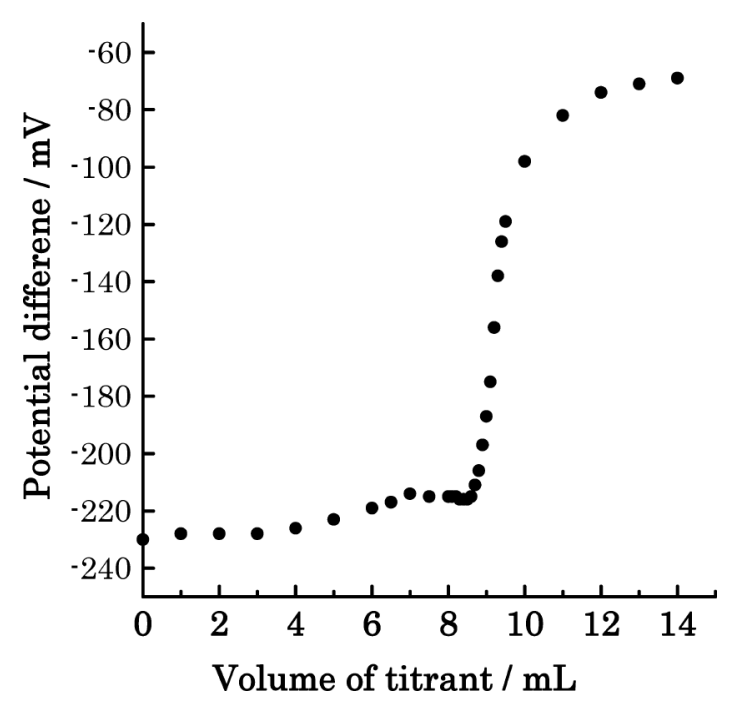

Fig. 2 Colloidal potentiometric titration curve of PVS $^{-}$with FeTMUA $^{+}$using a surfactant sensitive electrode

\section{2•4 CCD 型 $\mathrm{Ca}^{2+}$ イメージセンサーの調製と電位応答} 測定

使用した CCD 型 $\mathrm{pH}$ イメージセンサー ${ }^{15)}$ は, 16384 個 $(128 \times 128)$ のセンサーピクセルを持つアレイ型半導体セ ンサー（観察領域 $4.77 \mathrm{~mm} \times 4.77 \mathrm{~mm}$ ）である. 電池構成 は, 参照電極//電解溶液/イオン感応膜/半導体でイオン 感応膜型電界効果トランジスタ (ISFET) と同じである. ISFET では, イオン感応膜の電位変化をソースとドレイン 間に流れる電流または電圧を測定するが, CCD型イオンセ ンサーではシリコン半導体素子内部に形成される空乏層に 満たした電気量を計測する。空乏層のポテンシャル井戸の 深さは, イオン感応膜の電位に依存して変化する. ポテン シャルの井戸を電荷で満たして, その電気量を計測するこ とでイオン感応膜の電位を決定し, イオン濃度を測定す る. 詳細な原理と操作については, 既報 ${ }^{15)}{ }^{16)} に$ に示した.

$\mathrm{pH}$ に対する応答を確かめた CCD 型 $\mathrm{pH}$ イメージセン サーに $\mathrm{Ca}^{2+}$ イオノフォアを含む可塑化 PVC 膜を製膜し, $\mathrm{Ca}^{2+}$ イメージセンサーを作製した ${ }^{16)}$. 膜材料として PVC $14.5 \mathrm{mg}$, K23E1 $1.0 \mathrm{mg}$, NPOE $18.0 \mathrm{mg}$, POSS $15.0 \mathrm{mg}$, KTCPB $0.25 \mathrm{mg}$ を秤量し, THF $2.5 \mathrm{~mL}$ に溶解して, 膜溶 液を調製した。その膜溶液 $40 \mu \mathrm{L}$ を $10 \mu \mathrm{L}$ ずつ 4 回に分け

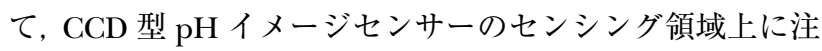
ぎ， 1 日室温で放置した. 製膜後, $1 \mathrm{mmol} \mathrm{L}^{-1}$ の硝酸カル シウム溶液で 12 時間のコンディショニングを行った.

3 結果と考察

\section{$3 \cdot 1$ 高分子電解質錯体の調製と分析}

$3 \cdot 1 \cdot 1$ 高分子電解質錯体の調製 コロイド滴定 ${ }^{17)} に$ より標定されたポリビニル硫酸 $\left(\mathrm{PVS}^{-}\right)$に FeTMUA ${ }^{+}$を加
えた $20 \mathrm{~mL}$ の混合溶液 $\left(\left[\mathrm{PVS}^{-}\right]=5 \mathrm{meq} \cdot \mathrm{L}^{-1},\left[\mathrm{FeTMUA}^{+}\right]\right.$ $=2.5 \mathrm{mM}$ ）を調製した. その混合溶液に, 飽和の塩化カル シウム水溶液を過剩に添加し, 黄色の沈殿を析出させた. このとき, FeTMUA ${ }^{+}$共存しない KPVS 溶液にカルシウ ム溶液を加えても沈殿は析出しなかった. 同様の操作でへ パリンの高分子電解質三元系錯体の沈殿を得た。一方, $\mathrm{PSS}^{-}$を使用して同様の調製を行ったが, 塩化カルシウムの 濃度を調整しても高分子電解質三元系錯体は析出しなかっ た.このように高分子陰イオンの種類によって沈殿が得ら れるかどうかは, FeTMUA ${ }^{+}$溶液中に高分子㓌イオンを添 加して得られる吸着ボルタンメトリーの FeTMUA ${ }^{+}$の濃度 依存性 ${ }^{12)}$ と類似していた。すなわち， $\mathrm{PVS}^{-}$の共存下での $\mathrm{FeTMUA}^{+}$の CP への吸着波は $\mathrm{PVS}^{-}$の濃度増加と共に大き くなるが, $\mathrm{PSS}^{-}$の共存下での FeTMUA ${ }^{+}$の CPへの吸着波 は $\mathrm{PSS}^{-}$の濃度が増加しても大きくならなかった. これは, PSS 錯体が水溶性であるため, CP に吸着し難かったと考え られた。

$3 \cdot 1 \cdot 2$ 高分子電解質錯体の分析 最初に, 界面活性 剂電極と $\mathrm{Ca}^{2+}$ 選択性電極の電位応答を確かめた. 界面活性 剤電極は, FeTMUA ${ }^{+}$濃度に対して正の電位応答を示すが 変動しやすく, 電位勾配は直線的ではなかった。 その電位 変化は $10^{-6} \mathrm{~mol} \mathrm{~L}^{-1}$ 以上で観測され, $10^{-6} \sim 10^{-5} \mathrm{~mol} \mathrm{~L}^{-1}$ で $20 \mathrm{mV}$ decade $^{-1}, 10^{-5} \sim 10^{-4} \mathrm{~mol} \mathrm{~L}^{-1}$ で $81 \mathrm{mV} \mathrm{decade}{ }^{-1}$ で あった。 また, FeTMUA ${ }^{+}$の臨界ミセル濃度 ${ }^{18)}$ である $10^{-4}$ $\mathrm{mol} \mathrm{L}{ }^{-1}$ 以上では電位は一定であった. $\mathrm{Ca}^{2+}$ 選択性電極の 電位応答は, $10^{-3} \sim 10^{-7} \mathrm{~mol} \mathrm{~L}^{-1}$ の $\mathrm{Ca}^{2+}$ の対数濃度に対し て直線的に増加し, その傾きは $28 \mathrm{mV} \mathrm{decade}{ }^{-1}$ であった.

$\mathrm{PVS}^{-}$と FeTMUA ${ }^{+}$との反応を調べるため, FeTMUA ${ }^{+}$に 応答する界面活性剂電極を用いて, $0.44 \mathrm{mmol} \mathrm{L}^{-1}$ の PVS 溶液 $10 \mathrm{~mL}$ を $0.5 \mathrm{mmol} \mathrm{L}^{-1}$ の FeTMUA ${ }^{+}$溶液で電位差コロ イド滴定を行った（Fig. 2).

$$
\mathrm{PVS}^{-}+\mathrm{FeTMUA}^{+} \longrightarrow \text { PVS-FeTMUA }
$$

式(1)の反応に従って進む滴定において，陽イオン界面活 性剤としてベンジルジメチルテトラデシルアンモニウムイ オン $\left(\mathrm{Zeph}^{+}\right)$を $\mathrm{PVS}^{-}$で滴定した場合には, 当量点前後で その濃度が大きく変化する対称的なシグモイド型曲線 ${ }^{19)} に$ なる.しかし，Fig. 2 に見られるように滴定曲線はシグモ イド型にはならず，当量点以降で急激に電位差が増加し， 次第に頭打ちになる曲線であった。これは, 界面活性剂電 極が低濃度の FeTMUA ${ }^{+}$に応答しないためであると考えら れた. 当量点以降に大きな電位差の増加があることから, 式(1)の反応で添加したほとんどすべての FeTMUA ${ }^{+}$が定 量的に反応したと考えられる.

次に, $\mathrm{PVS}^{-} と \mathrm{Ca}^{2+}$ との反応（式 $(2)$ ) を調べるために, $\mathrm{Ca}^{2+}$ 選択性電極を用いて, $0.44 \mathrm{mmol} \mathrm{L}^{-1}$ の $\mathrm{PVS}^{-}$溶液 


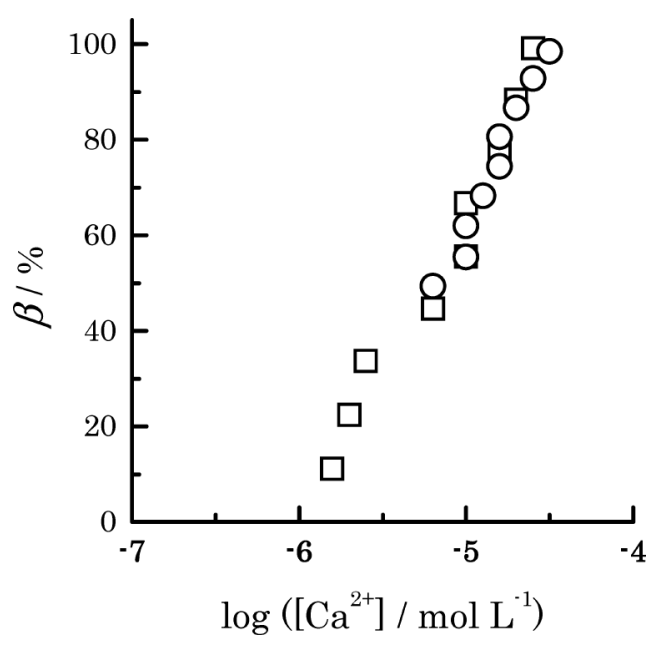

Fig. 3 Reaction ratio $(\beta)$ of $\mathrm{PVS}^{-}$with $\mathrm{Ca}^{2+} ; \square$, without FeTMUA $^{+}$; $\bigcirc$, with FeTMUA $^{+}$(a half equivalent mole of $\mathrm{PVS}^{-}$)

$10 \mathrm{~mL}$ を $1 \mathrm{mmol} \mathrm{L}^{-1}$ の $\mathrm{Ca}^{2+}$ 溶液で電位差滴定を行った.

$$
2 \mathrm{PVS}^{-}+\mathrm{Ca}^{2+} \longrightarrow \mathrm{Ca}-\mathrm{PVS}_{2}
$$

電位差滴定は凸型の緩慢な電位上昇曲線を示し, 当量点付 近でも明瞭な終点を示さなかった。 これは, 式(2)の生成 定数があまり大きくないことを示していると考えられた. そこで, $\mathrm{PVS}^{-}$の半当量の FeTMUA ${ }^{+}$含む $0.44 \mathrm{mmol} \mathrm{L}^{-1}$ の $\mathrm{PVS}^{-}$溶液 $10 \mathrm{~mL}$ を $50 \mathrm{mmol} \mathrm{L}^{-1}$ の $\mathrm{Ca}^{2+}$ 溶液で電位差滴 定を行った. この滴定の反応は, 式(3)のようになる.

$$
2 \mathrm{PVS}_{2}-\mathrm{FeTMUA}^{-}+\mathrm{Ca}^{2+} \longrightarrow \mathrm{Ca}\left(\mathrm{PVS}_{2}-\mathrm{FeTMUA}\right)_{2}
$$

この場合も, 明瞭な終点が得られず, 凸型の緩慢な電位上 昇曲線を示した。 これらの滴定曲線から, $\mathrm{Ca}^{2+}$ 選択性電極 の観測電位を $\mathrm{Ca}^{2+}$ 濃度に換算して, 式(4)もしくは式(5)を 用いて遊離の $\mathrm{Ca}^{2+}$ 濃度に対する $\mathrm{PVS}^{-}$との反応率 $\beta$ を算出 した.

$$
\begin{aligned}
\beta & =\frac{2\left[\mathrm{Ca}-\mathrm{PVS}_{2}\right]}{\left[\mathrm{PVS}^{-}\right]_{\text {total }}}=\frac{2\left\{\left[\mathrm{Ca}^{2+}\right]_{\text {total }}-\left[\mathrm{Ca}^{2+}\right]\right\}}{\left[\mathrm{PVS}^{-}\right]_{\text {total }}} \\
\beta & =\frac{2\left[\mathrm{Ca}\left(\mathrm{PVS}_{2}-\mathrm{FeTMUA}_{2}\right]\right.}{\left[\mathrm{PVS}^{-}\right]_{\text {total }}} \\
& =\frac{2\left\{\left[\mathrm{Ca}^{2+}\right]_{\text {total }}-\left[\mathrm{FeTMUA}^{+}\right]_{\text {total }}-\left[\mathrm{Ca}^{2+}\right]\right\}}{\left[\mathrm{PVS}^{-}\right]_{\text {total }}}
\end{aligned}
$$

下付きの total は添加した総量を示す。それらの結果を Fig. 3 に示す. いずれの場合も, その反応率は $\mathrm{Ca}^{2+}$ 濃度が $10^{-6} \mathrm{~mol} \mathrm{~L}^{-1}$ から $10^{-5} \mathrm{~mol} \mathrm{~L}{ }^{-1}$ にかけて上昇している.

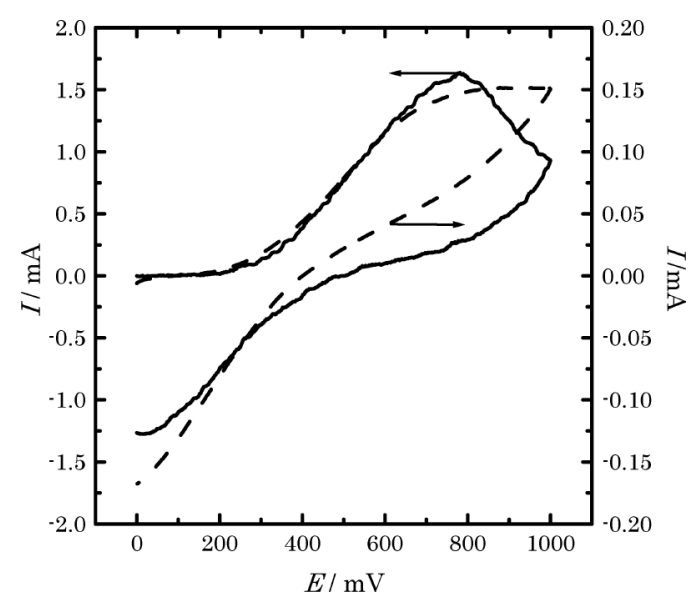

Fig. 4 Cyclic voltammograms of CP $\left(\begin{array}{lll}\phi & \mathrm{mm})\end{array}\right.$ included $2.4 \%$ of the ternary complex; -, PVS complex; --- , Heparin complex

式(1)の反応が完全に進むと仮定した式(5)から得られる $\mathrm{FeTMUA}^{+}$の共存下における錯体の中の $\mathrm{PVS}^{-}$に対する反応 率は, 式(4)に基づく $\mathrm{PVS}^{-}$に対する反応率に一致してい る. すなわち, $\mathrm{PVS}^{-}$と $\mathrm{Ca}^{2+}$ の反応に対して $\mathrm{FeTMUA}^{+}$の共 存が, その反応を促進したり, 逆に阻害したりするような 協同効果 ${ }^{20)} に$ 変化を生じさせるようなことはないことが分 かった. 一方, 界面活性剂電極において, 観測電位から, 当量点前の $\mathrm{FeTMUA}^{+}$の濃度は $10^{-6} \mathrm{~mol} \mathrm{~L}^{-1}$ 以下であり, 当 量点前の $\mathrm{FeTMUA}^{+}$の濃度に対する $\mathrm{PVS}^{-}$の反応率は計算 できなかった. 当量点前で FeTMUA ${ }^{+}$の濃度が $10^{-6} \mathrm{~mol} \mathrm{~L}^{-1}$ 以下であることは, 少なくとも $\mathrm{Ca}^{2+}$ より $\mathrm{PVS}^{-}$と低濃度で 反応しやすいことを示している，三元系錯体では，PVS に FeTMUA ${ }^{+}$が優先的に凝集して結合しやすく, $\mathrm{Ca}^{2+}$ は残り の電荷を埋めるように結合していることが考えられた.

\section{$3 \cdot 2$ 高分子電解質錯体を含む $\mathrm{CP}$ 電極の $\mathrm{Ca}^{2+}$ 放出と評価}

$\mathbf{3} \cdot \mathbf{2} \cdot \mathbf{1} \quad$ サイクリックボルタンメトリー $\quad 10 \mathrm{mmol} \mathrm{L}^{-1}$ の $\mathrm{NaCl}$ 溶液中で, $2.4 \%$ の三元系錯体を含む $\mathrm{CP}$ のサイク リックボルタモグラムを Fig. 4 に示す.CP 電極単独及び $\mathrm{CaCl}_{2}$ や KPVS を数\% 含む $\mathrm{CP}$ 電極のサイクリックリック ボルタモグラムでは, $0 \sim 1000 \mathrm{mV}$ で数 $10 \mu \mathrm{A}$ の電流増加 を示すものの, FeTMUA ${ }^{+}$が共存する場合に見られるよう に $1 \mathrm{~mA}$ 以上流れる有意な電流増加は見られなかった. 先 の研究 ${ }^{21)}$ で FeTMUA ${ }^{+}$の吸着ボルタモグラムは, 共存陰イ オンと FeTMUA ${ }^{+}$の濃度によって変化するが, その酸化波 は $200 \sim 300 \mathrm{mV}$ 付近にあった. また，対アニオンとして 疎水性の強いイオンとの会合の場合には, DOP と溶媒和 していると考えられるもう一つの酸化波が $400 \mathrm{mV}$ 以上の

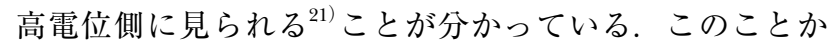
ら, $800 \mathrm{mV}$ の PVS 錯体のピーク電位は, CP 電極内で PVS に結合した FeTMUA ${ }^{+}$が溶媒であるDOPに囲まれた疎水 


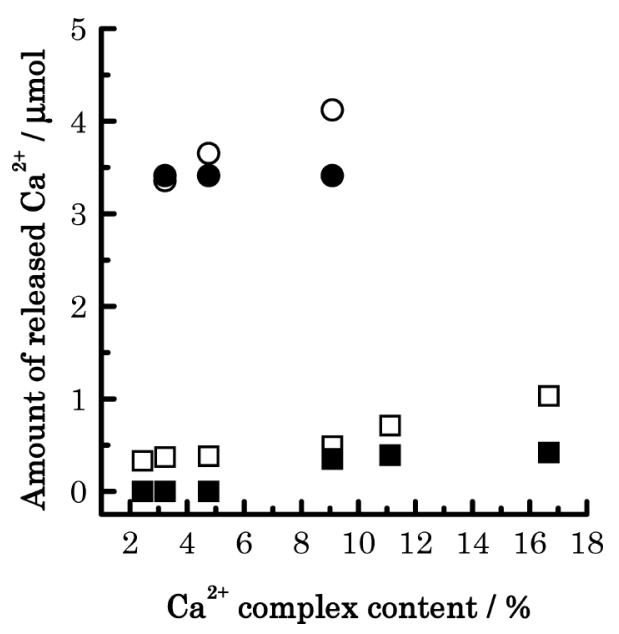

Fig. 5 The amount of released $\mathrm{Ca}^{2+}$ from $\mathrm{CP}(\phi 3$ $\mathrm{mm}$ ) including various content of the ternary complex by a coulometry; $\square$, PVS complex with the electrolysis; $\square$, PVS complex without the electrolysis; $\bigcirc$, Heparin complex with the electrolysis; 0 , Heparin complex without the electrolysis

性環境にあるために, 酸化電位が高電位側にあるものと考 えられる.一方, ヘパリン錯体のボルタモグラムは高電位 側で電流は増加するが, PVS 錯体と比べて電流は 10 分の 1 であり, $800 \mathrm{mV}$ 以上でほぼ一定の電流が得られた。これ は錯体中に FeTMUA ${ }^{+}$量が少ないか, 溶液中に FeTMUA ${ }^{+}$ が流出しやすい状態にあるためと考えられる.

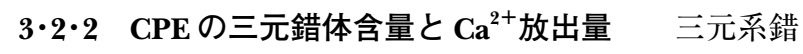
体量を変えることで数種の CP 調製し, CP 電極を使用し て定電位電解 (時間 : 5 分, 電位 : $800 \mathrm{mV}$, 電解溶液 : 10 $\mathrm{mmol} \mathrm{L}{ }^{-1} \mathrm{NaCl}$ ) で $\mathrm{Ca}^{2+}$ 放出を行い, $\mathrm{Ca}^{2+}$ が放出された水 溶液を原子吸光分析によって測定し，その放出量を算出し た (Fig. 5)，両錯体とも含有量の増加とともに $\mathrm{Ca}^{2+}$ 放出量 $^{2}$ は多くなっている.ヘパリン錯体は同じ含有量の PVS 錯体 と比較すると, $\mathrm{Ca}^{2+}$ 放出量がはるかに多かった。 しかし, 無電解時にも同量に近い $\mathrm{Ca}^{2+}$ 放出が見られ, $\mathrm{Ca}^{2+}$ の放出 は電解によらずに起こっていることが分かった. PVS 錯体 の場合, 錯体含有量が多い時には無電解時に $\mathrm{Ca}^{2+}$ の放出が 見られるが，錯体含有量が少量であれば無電解時の $\mathrm{Ca}^{2+}$ の 漏れは観測できなかった. PVS 錯体を含む $\mathrm{CP}$ は電解によ る放出のスイッチングが可能である.

Fig. 6 に Fig. 5 と同じ条件で 5 分間の PVS 錯体を含む CP の定電位電解を行ったときの時間－電気量の曲線を示す. PVS 錯体濃度が $2.4 \%$ 及び $3.2 \%$ のときに, 電気量は 15 秒以内で急激に増加し, それ以降はゆるやかに増加してい る.一方, $9.1 \%$ のときには電気量は 5 分まで増加し続け ている.

Fig. 7 に, Fig. 5 での $\mathrm{Ca}^{2+}$ 放出量を基に換算した電気量 と, Fig. 6 での最終電気量を PVS 錯体の濃度別に示す.い

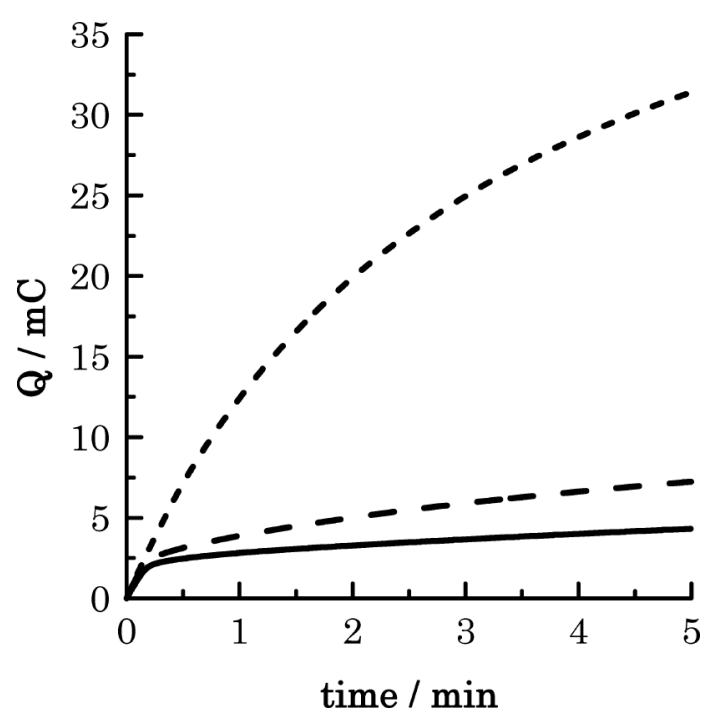

Fig. 6 Chronocoulometry of CP ( $\phi 3 \mathrm{~mm})$ including various content of the ternary complex. Solid line, $2.4 \%$ complex CP; dashed line, $3.2 \%$ complex CP, short dashed line, $9.1 \% \mathrm{CP}$

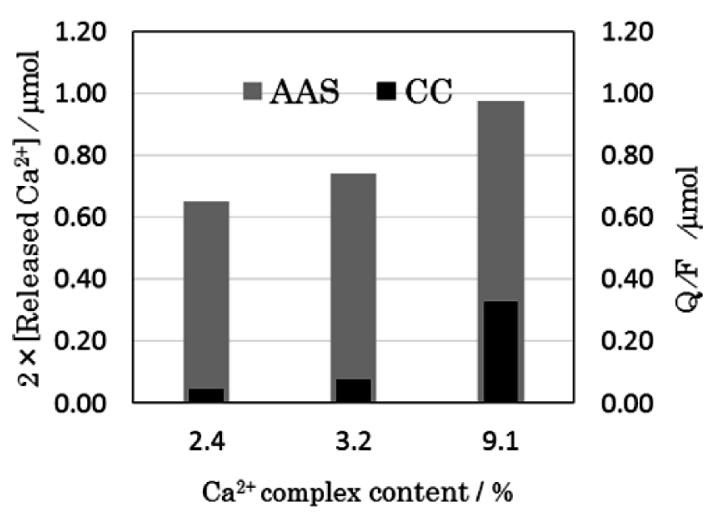

Fig. 7 Total electric charges for released $\mathrm{Ca}^{2+}$ measured by atomic absorption spectroscopy (AAS), and for the chronocoulometry (CC) of the CPs for 5 $\min$

ずれの場合も $\mathrm{Ca}^{2+}$ 放出量を基に換算した電気量は, 電解時 の電気量よりも大きかった. $2.4 \%$ で 15 倍, $3.2 \%$ で 10 倍, $9.1 \%$ で 3 倍であった. すなわち, 電解放出以外に電 解によらない方法でも $\mathrm{Ca}^{2+}$ が放出していることが分かっ た. 低含有量では電解後の CP 電極表面に変化がほとんど 見られなかったが, 高含有量では, 明らかに電解後の電極 表面が荒れていた，そこで， $9.1 \%$ の CPでは，表面層に 近い内部の三元系錯体からも $\mathrm{Ca}^{2+}$ が放出されたものと考 えられる。

\section{3・3 CCD 型 $\mathrm{Ca}^{2+}$ イメージセンサーを用いた評価}

Fig. 8 に示すように装置を設置して, $10 \mathrm{mmol} \mathrm{L}^{-1}$ トリス 緩衝溶液中で，口径 $500 \mu \mathrm{m}$ のマイクロデバイス（電解質 


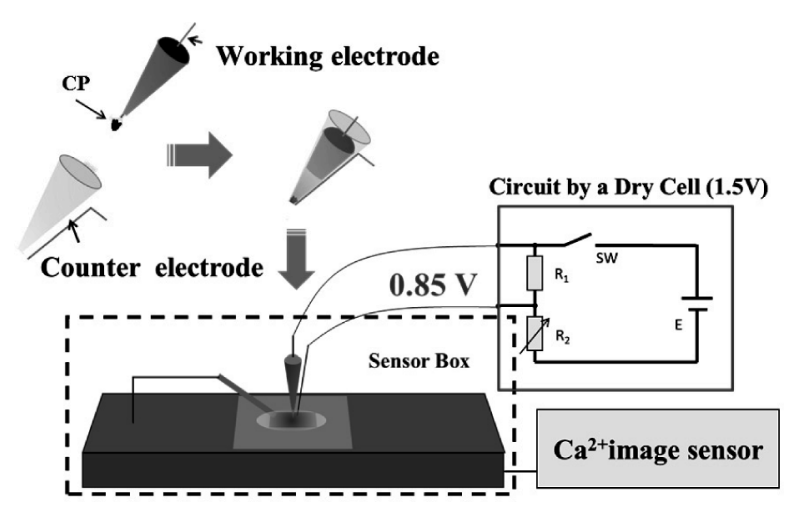

Fig. 8 Schematic diagram of the real-time measurement system of the micro $\mathrm{Ca}^{2+}$-release device using CCD $\mathrm{Ca}^{2+}$ image sensor
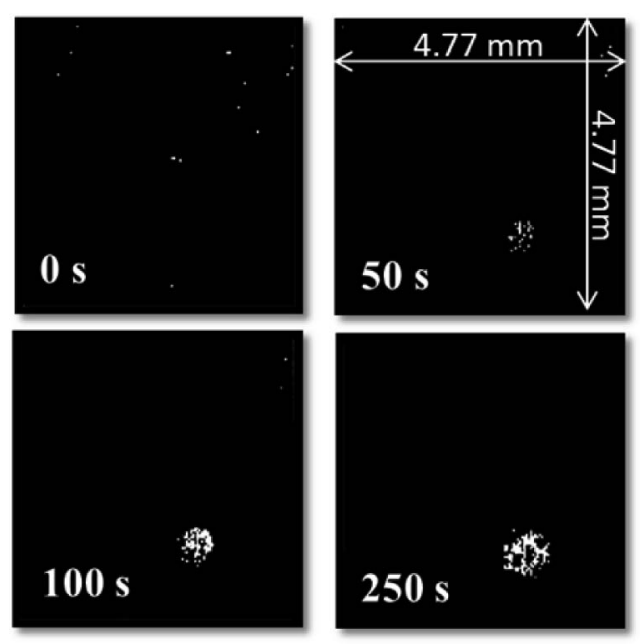

Fig. 9 Real-time images of the change in $\mathrm{Ca}^{2+}$ concentration after the electrolysis of the micro $\mathrm{Ca}^{2+}$ release device

The micro device was set over the bottom right. The white areas indicate the high concentration of $\mathrm{Ca}^{2+}$.

錯体含有率 $2.4 \%$ ）の電解による $\mathrm{Ca}^{2+}$ 放出を $\mathrm{CCD}$ 型 $\mathrm{Ca}^{2+}$ イメージセンサーで動画計測した。 このマイクロデバイス の電解において, 3 電極を用いると, $\mathrm{CCD}$ 型 $\mathrm{Ca}^{2+}$ イメージ センサー側の参照電極と競合を起こして CCD 型 $\mathrm{Ca}^{2+}$ イ メージセンサーの観測電位が大きく変動してしまい, 濃度 変化に対する有効な電位応答が得られなかった。 そこで, デバイス側は参照電極を用いずに白金電極との 2 電極方式 で印加電圧を $850 \mathrm{mV}$ として電解した. $300 \mathrm{~s}$ 間のリアルタ イム計測での $\mathrm{Ca}^{2+}$ 放出の動画画像の一部を Fig. 9 に示す. 動画画像から明らかなように, 右下に設置したマイクロデ バイスの近傍の $\mathrm{Ca}^{2+}$ 濃度だけが局所的に増加しているこ とが確かめられた。

マイクロデバイス直下での時間 - 観測電位曲線 (A）と, その遠方における時間－観測電位曲線（B）を Fig. 10 に示

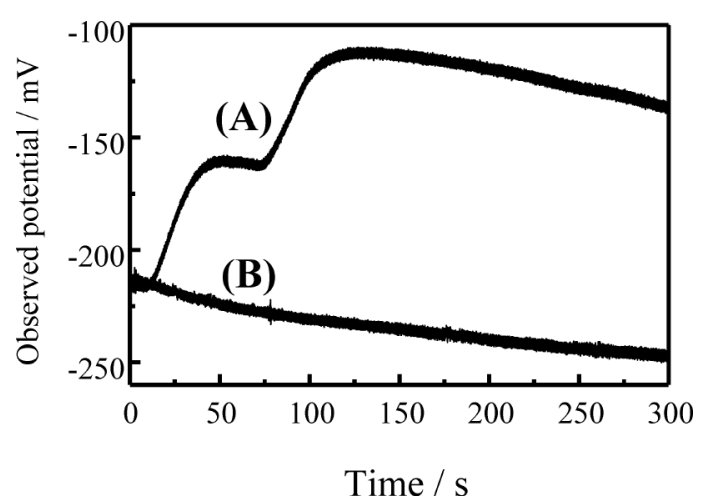

Fig. 10 Observed potential profiles of the sensing pixel just under the micro $\mathrm{Ca}^{2+}$-release device (A), and the sensing pixel on the other place (B)

す.ここで，デバイスとイメージセンサーの感応膜の距離 は，検出時間と濃度に影響したが，デバイスと感応膜間の 距離を直接測定することができなかったので， $3 \mathrm{~mm}$ 以下 になるように電極を近づけた。（A）においては，観測電位 が約 50 秒で一度一定になるが，75秒付近から再び上昇を 始めている。一方，（B）においては，観測電位は低下する だけで増加は見られない.（B）において観測電位から推定 される $\mathrm{Ca}^{2+}$ 濃度は $10^{-7} \mathrm{~mol} \mathrm{~L}^{-1}$ 以下を示していた（A）で の 1 段目で一定になる観測電位を $\mathrm{Ca}^{2+}$ 濃度に換算すると $10^{-6} \mathrm{~mol} \mathrm{~L}^{-1}$ 程度であり,ささらに75 秒以降に増加した $\mathrm{Ca}^{2+}$ 濃度は $10^{-4} \mathrm{~mol} \mathrm{~L}^{-1}$ に近い值まで増加した. 1 段目の濃度か ら 100 倍近く濃度が増加していたことと, Fig. 7 で見られ た電解量の 15 倍の $\mathrm{Ca}^{2+}$ 放出量があったことを考えると, 長時間の電解によって電極表面が崩壊して電解によらない $\mathrm{Ca}^{2+}$ 放出が起きたと考えられた。

先に CCD 型 $\mathrm{K}^{+}$イメージセンサーを用いて参照電極から

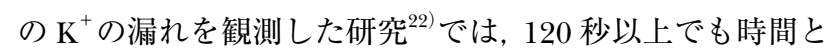
ともに $\mathrm{K}^{+}$の濃度は増加した。一方, $\mathrm{CCD}$ 型 $\mathrm{Na}^{+}$イメージ センサーを用いたイオン交換樹脂 1 粒のイオン交換挙動の 研究 ${ }^{23)}$ における $\mathrm{Na}^{+}$測定では, $\mathrm{Ba}^{2+}$ との交換で 30 秒後, $\mathrm{Ca}^{2+}$ との交換で 60 秒後に，その濃度が一定になった．前 者は, 大きな濃度勾配による拡散と高密度による下降流で 高濃度の $\mathrm{K}^{+}$が連続的に放出される系であり，後者は主に 境界膜界面でのイオン交換による界面濃度に依存した $\mathrm{Na}^{+}$ の拡散で, 放出量が漸次減少する系であった。本実験の場 合には, Fig. 6 に示すようにおよそ 15 秒以内で電解量が急 激に減少したため, デバイス表面からの電解に依存した放 出は短時間でほぼ終わると考えられる. Fig. 10 から, デバ イスとセンサー間の距離のために時間的な遅れはあるが, 50 秒で 1 段目の電位が一定になったことはこれを示唆して いる. そこで, 作製したデバイスの短時間の電解ならば, その電解の時間制御により $\mathrm{Ca}^{2+}$ の微量放出量を調整でき ると思われる. 


$$
4 \text { 結 言 }
$$

$\mathrm{PVS}^{-}, \mathrm{Ca}^{2+}, \mathrm{FeTMUA}{ }^{+}$から構成される高分子電解質錯 体を調製し, 電極活性物質の酸化還元反応を利用した $\mathrm{Ca}^{2+}$ 局所放出電気化学デバイスの作製を行った. 二元系錯体と 三元系錯体の電位差滴定の研究から, $\mathrm{Ca}^{2+}$ は弱く $\mathrm{PVS}^{-}$に 結合しているものと推察された.

低濃度の三元系錯体を含む $\mathrm{CP}$ 電極では, 電解によって のみ $\mathrm{Ca}^{2+}$ の放出が見られることが, 原子吸光法により確か められた。しかし, クーロメトリーによる研究から, 電解 を開始後では, 電気量によらずに多量の $\mathrm{Ca}^{2+}$ が放出されて いることが明らかになった。

$\mathrm{CCD}$ 型 $\mathrm{Ca}^{2+}$ イメージセンサーの動画計測により, 電解 時に $\mathrm{CP}$ 電極直下でのみ $\mathrm{Ca}^{2+}$ 濃度増加が見られ, その他の 場所ではまったく見られないことが分かった。さらに, $\mathrm{Ca}^{2+}$ の濃度上昇が 2 段階の時間差で起こったことが明らか になり, 最初に電解に依存した放出が起ったのちに, 電極 の表面の崩壊により電極内部からも $\mathrm{Ca}^{2+}$ が放出されたこ とが考えられた。

以上の結果により, 電解スイッチングにより局所での $\mathrm{Ca}^{2+}$ の放出に成功した. また, $\mathrm{Ca}^{2+}$ の微量な放出量の観察 及び放出メカニズムの解析に $\mathrm{CCD}$ 型 $\mathrm{Ca}^{2+}$ イメージセン サーが有用であることが分かった.

\section{謝辞}

本研究を遂行するに当たって, 経費の一部はJSPS科研費 及び CREST の助成を受けた。ここに謝意を表します。

\section{文献}

1) 曽我部正博: 生物物理, $\mathbf{4 0 , 3 1}$ (2000).

2) 米村重信: 生物物理, 51, 162 (2011).

3) 小山純弘, 相澤益男: 化学と生物, 38, 503 (2000).

4) R. D. Purves: “MICROELECTRODE METHODS FOR INTRACELLULAR RECORDING AND IONO-
PHORESIS", (1981), (Academic Press, London).

5) 古田寿昭, 鈴木商信 : 生化学, 83, 966 (2011).

6) T. Hattori, Y. Tamamura, K. Tokunaga, T. Sakurai, R. Kato, K. Sawada : Anal. Chem., 86, 4196 (2014).

7) 御子柴克彦, 遠藤 寛, 宮本英七編 : “カルシウム イオンとシグナル伝達”, (2000), (共立出版株式会 社).

8) M. Endo, M. Tanaka, Y. Ogawa : Nature, 228 (5266), 34 (1970).

9) Y. Moriyama, H. Okamoto, H. Asai : Biophys J., 76, 993 (1997).

10) V. Bhaktavatsalam, A. Shvarev, E. Bakker : Analyst, 131, 895 (2006).

11) Y. Cheng, X. Luo, J. Betz, G. F. Payne, W. E. Bentley, G. W. Rubloff : Soft Matter, 7, 5677 (2011).

12) T. Hattori, M. Nakayama : Electroanalysis, 17, 613 (2005).

13) T. Masadome, T. Imato, N. Ishibashi : Anal. Sci., 3, 121 (1987).

14) K. Suzuki, K. Watanabe, Y. Matsumoto, M. Kobayashi, S. Sato, D. Siswanta, H. Hisamoto : Anal. Chem., 67, 324 (1995).

15) M. Futagawa, D. Suzuki, R. Otake, F. Dasai, M. Ishida, K. Sawada : IEEE Trans. Electron Devices, 60, 2634 (2013).

16) 服部敏明, 櫻井孝司, 加藤絢巳, 加藤 亮, 平田幸 夫, 澤田和明: 分析化学 (Bunseki Kagaku), 63, 119 (2014).

17) T. Hattori, S. Munezane, R. Kato, T. Kawauchi : Chitin and Chitosan Research, 15, 13 (2009).

18) B. S. Gallardo, M. J. Hwa, N. L. Abbot : Langmuir, 11, 4209 (1995).

19) 服部敏明, 内藤洋子, 伊藤義徳, 加藤 亮, 平田幸 夫, 吉野明広：分析化学 (Bunseki Kagaku), 60, 419 (2011).

20) 服部敏明, 服部貞雄, 加藤正直：分析化学 (Bunseki Kagaku), 43, 777 (1994).

21) T. Hattori, S. Tanaka : Electroanalysis, 15, 1522, (2003).

22) T. Hattori, Y. Masaki, K. Atsumi, R. Kato, K. Sawada: Anal. Sci., 26, 1039 (2010).

23) T. Hattori, Y. Masaki, S. Mori, D. Miyamoto, R. Kato, K. Sawada : Electroanalysis, 24, 114 (2012). 


\title{
Fabrication and Evaluation of Calcium Ion Releasing Electrochemical Device Using a Ternary Complex
}

\author{
Kenji Hirota $^{1}$, Ryo Kato ${ }^{2}$, Kazuaki SAwAdA ${ }^{1}$ and Toshiaki Hattori ${ }^{* 1}$ \\ * E-mail : thattori@ee.tut.ac.jp \\ ${ }^{1}$ Department of Electrical \& Electronic Information Engineering, Toyohashi University of Technology, 1-1, \\ Hibarigaoka, Tempaku-cho, Toyohashi-shi, Aichi 441-8580 \\ ${ }^{2}$ Cooperative Research Facility Center, Toyohashi University of Technology, 1-1, Hibarigaoka, Tempaku-cho, \\ Toyohashi-shi, Aichi 441-8580
}

(Received 18 August 2016, Accepted 29 September 2016)

The $\mathrm{Ca}^{2+}$-release device was a carbon paste electrode including a ternary complex consisting of poly(vinyl sulfate) ion $\left(\mathrm{PVS}^{-}\right)$, 11-ferrocenylammonium ion trimethylundecyl $\left(\mathrm{FeTMUA}^{+}\right)$, and $\mathrm{Ca}^{2+}$. The ternary complex was characterized by potentiometric titrations. The potentiometric colloidal titration of $\mathrm{PVS}^{-}$with $\mathrm{FeTMUA}^{+}$using a surfactant electrode indicated that the potentials in the titration curve sharply increased at the equivalent point, and then the complexation was strong. The potentiometric titration of $\mathrm{PVS}^{-}$with $\mathrm{Ca}^{2+}$ using a $\mathrm{Ca}^{2+}$-selective electrode had no significant endpoint because of weak complexation. The binding behavior of $\mathrm{Ca}^{2+}$ with $\mathrm{PVS}^{-}$was independent of the co-existence of FeTMUA ${ }^{+}$. The carbon paste electrode (CPE) including the ternary complex was characterized by cyclic voltammetry. The peak of the oxidation wave of $\mathrm{FeTMUA}^{+}$was observed at $800 \mathrm{mV}$ (vs. saturated $\mathrm{Ag} / \mathrm{AgCl}$ ), which was larger than the oxidation potential of $\mathrm{FeTMUA}^{+}$adsorbed on CPE from an aqueous solution. The release amount of $\mathrm{Ca}^{2+}$ was evaluated by atomic adsorption spectroscopy. After electrolysis, the release amount of $\mathrm{Ca}^{2+}$ increased with the content amount; the high content CPE released $\mathrm{Ca}^{2+}$ even without electrolysis, but the low content CPE did not release a significant amount without electrolysis. At last, a $\mathrm{Ca}^{2+}$ release electrochemical device was fabricated; a thin end $(\phi 0.5 \mathrm{~mm})$ of a polypropylene tip was stopped with the CPE and a Pt wire inserted into the CPE. The slight amount of $\mathrm{Ca}^{2+}$ released from the limited area of the tip was monitored by a CCD $\mathrm{Ca}^{2+}$ image sensor. The released amount of $\mathrm{Ca}^{2+}$ increased with the electrolysis time only just under the tip, while the other area had no significate change of $\mathrm{Ca}^{2+}$. The small device can locally release $\mathrm{Ca}^{2+}$ to only a limited area. In addition, the analysis of the image sensor displayed that the $\mathrm{Ca}^{2+}$ release of the device was a two-stage discharge: in first stage $\mathrm{Ca}^{2+}$ released from the surface, and in second stage a large amount of $\mathrm{Ca}^{2+}$ was released independent of electrolysis. The CCD $\mathrm{Ca}^{2+}$ image sensor was very useful to characterize the $\mathrm{Ca}^{2+}$ release device.

Keywords: $\mathrm{Ca}^{2+}$-release electrochemical device; anionic polyelectrolyte; electroactive cationic surfactant; CP; CCD Ca ${ }^{2+}$ image sensor. 